\title{
Computer Forensics for Graduate Accountants: A Motivational Curriculum Design Approach
}

Grover S. Kearns

University of South Florida, St. Petersburg

Follow this and additional works at: https://commons.erau.edu/jdfs|

Part of the Computer Engineering Commons, Computer Law Commons, Electrical and Computer Engineering Commons, Forensic Science and Technology Commons, and the Information Security Commons

\section{Recommended Citation}

Kearns, Grover S. (2010) "Computer Forensics for Graduate Accountants: A Motivational Curriculum Design Approach," Journal of Digital Forensics, Security and Law. Vol. 5 : No. 2 , Article 5.

DOI: https://doi.org/10.15394/jdfsl.2010.1076

Available at: https://commons.erau.edu/jdfsl/vol5/iss2/5

This Article is brought to you for free and open access by

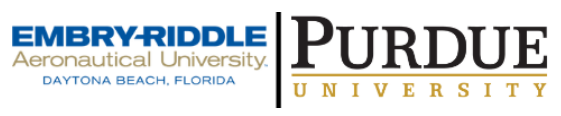
the Journals at Scholarly Commons. It has been accepted for inclusion in Journal of Digital Forensics, Security and Law by an authorized administrator of Scholarly Commons. For more information, please contact commons@erau.edu.

(c)ADFSL 


\title{
Computer Forensics for Graduate Accountants: A Motivational Curriculum Design Approach
}

\author{
Grover S. Kearns, Ph.D., CPA, CFE \\ College of Business \\ $1407^{\text {th }}$ Avenue South \\ University of South Florida St. Petersburg \\ St. Petersburg, FL 33701 \\ Phone: 727-553-4085 \\ Email: gkearns@stpt.usf.edu
}

\begin{abstract}
Computer forensics involves the investigation of digital sources to acquire evidence that can be used in a court of law. It can also be used to identify and respond to threats to hosts and systems. Accountants use computer forensics to investigate computer crime or misuse, theft of trade secrets, theft of or destruction of intellectual property, and fraud. Education of accountants to use forensic tools is a goal of the AICPA (American Institute of Certified Public Accountants). Accounting students, however, may not view information technology as vital to their career paths and need motivation to acquire forensic knowledge and skills. This paper presents a curriculum design methodology for teaching graduate accounting students computer forensics. The methodology is tested using perceptions of the students about the success of the methodology and their acquisition of forensics knowledge and skills. An important component of the pedagogical approach is the use of an annotated list of over 50 forensic web-based tools.
\end{abstract}

Keywords: Accounting, auditing, forensics, learning styles, MBA, curriculum design.

\section{INTRODUCTION}

The field of digital or computer forensics has become increasingly important to various disciplines and has had a dramatic impact on the accounting discipline. The AICPA and PCAOB (Public Company Accounting Oversight Board) have issued statements regarding auditors' increased responsibility for IT knowledge, fraud recognition and the importance of evaluating IT controls during a financial audit. The Sarbanes-Oxley Act of 2002 (SOX, 2002), increased evidence of business fraud and advancements in IT networks and systems should lead organizations to a higher expectation of auditors' IT skills (Sumners and Soileau, 2008). 
The difference between what the public expects from external auditors and the auditors' own views of their responsibilities is referred to as the "expectations gap.” Lynn Turner, former SEC chief accountant, states that past audit failures and well publicized financial scandals have widened this gap (Turner, 2002). Enron, WorldCom, Adelphia, and Qwest (the Big Four) alone cost investors and pensioners more than $\$ 460$ billion. These scandals which involved "cooking the books" went undetected by auditors and have created greater distrust of accountants in general. This perceived distrust in the quality of financial information may actually affect the proper functioning and integrity of the capital markets (Rezaee and Crumbley, 2007).

The AICPA, in its Statement on Auditing Standards No. 99 (SAS 99), Consideration of Fraud in a Financial Statement Audit (AICPA, Professional Standards, vol. 1, AU sec. 316), states that an "auditor may respond to an identified risk of material misstatement due to fraud by assigning ...forensic specialists.”

SAS 99 suggests several procedures that are forensic in nature. These involve the performance of substantive tests or the application of methods and techniques of evidence collection based upon the possibility of fraud at various levels of management, including override of internal controls, falsification of financial statements, misappropriation of assets, and collusion. Examples include extended interviews of financial and non financial personnel, surprise audits including recounts of inventories, tests of low risk accounts, and special tests not ordinarily performed (SAS 99). Even prior to the Big Four scandals the "Panel of Audit Effectiveness" on August 31, 2000, stated that "auditors should perform some 'forensic-type' procedures on every audit to enhance the prospects in the detection of financial statement fraud” (AICPA, 2000).

In response to the crisis of distrust, the AICPA has committed to six leadership roles to help restore confidence in the financial reporting process (Melancon, 2002). These include a role to promote academic research in how to strengthen antifraud education in the accounting curriculum.

Recent studies found that accounting students lack the requisite IT knowledge and skills to perform satisfactorily in their careers positions (Ahmed, 2003; AbuMusa, 2008). Foundation knowledge should include topics focusing on IT security issues, IT auditing, IT governance, computer based analytical methods and general forensic and fraud investigative auditing knowledge techniques. Textbooks for a foundation class today typically devote separate chapters to each of these topics (Buckoff and Schrader, 2000; Crumbley et al., 2007).

An understanding of IT and related controls is important to accounting students (Van Grembergen, De Haes and Moons, 2005). Internal control, as defined by COSO (1992), is the process designed to help firms achieve objectives in the effective and efficient use of resources, reliable financial reporting, and compliance with applicable laws and regulations. IT controls increase an 
organization's requirement for specialized knowledge and skill and are thus more costly to implement than other types of controls (ITGI, 2004; Cerullo and Cerullo, 2005). Understanding these controls is paramount to the effectiveness of both internal and financial auditors. While the adoption of computer-based auditing systems has steadily increased, a lack of IT education and background has prevented many auditors from integrating the necessary IT knowledge and skills with their professional knowledge (Davis, Schiller and Wheeler, 2007). This impairs the ability of the auditor in conducting appropriate tests on the relevant IT controls (Li, Huang and Lin, 2007).

Auditors with forensic IT skills have been in increased demand as a result of new regulatory requirements for compliance and higher emphasis on IT governance (Hoffman, 2004). The knowledge and skills for these professionals extend well beyond those for traditional auditors and, ideally, are a blend of accounting, forensic investigative and IT knowledge and skills. Most programs in accountancy, however, have not addressed the integration of the more traditional accounting with forensics and IT knowledge and skills Auditors who are educated and experienced in all of these areas become a valuable resource as either an IT auditor or internal auditor (Kearns, 2006).

Graduate accounting students often lack interest in information technology and may not understand the relevance of IT to their own career success (Kearns, 2009). Thus, the teacher is challenged to motivate the students and to encourage them to acquire IT knowledge by developing a positive attitude (Cangemi, 2000). Merhout and Buchman (2007) state that the education of IT auditors requires a blending of skills and educators "should strive to cultivate such a positive attitude in their students, and they should also make their students aware of the potential opportunities in the challenging IT audit career path.”

The purpose of this paper is to present a methodology, based upon established learning theories, for motivating accounting students to acquire skills and knowledge in a body of forensic tools commonly used in auditing. These tools are available on the Internet and can be used to develop an understanding of their application in a forensic auditing context. The paper also includes an annotated list of over 50 forensic tools for use by accountants in an appendix.

\section{LEARNING STYLE THEORIES}

Learning style theories state that different individuals perceive and process information differently. Therefore, to be successful, educators must strive to present information in different ways in order to support different learning styles. Two main learning styles are perceivers and processors. The concrete perceivers absorb information through direct experience while abstract perceivers rely upon analysis and observation. Active processors make immediate use of information in order to make sense of it while reflective processors reach cognitive awareness by 
simply thinking about the information. Traditionally, teaching has favored abstract perceiving and reflective processing. To be more effective, teachers must adopt styles that can motivate all students and provide for higher levels of interaction to increase the benefits for concrete perceivers and active processors. A brief discussion of three models expected to support and motivate accounting students of all learning styles follows.

\subsection{ARCS Model of Motivational Design}

The ARCS Model of Motivational Design is a method for improving the motivation of instructional material by presenting material in a way that is aligned with the learner's motivational needs. It suggests that student motivation can be influenced through development of strategies in four areas: Attention, Relevance, Confidence, Satisfaction (Keller, 1987).

Attention can be gained through incorporating novel approaches, stimulating questions or problems for the student to solve, interactive methods, specific examples, and varying the material. Relevance is defined as the extent to which information is perceived as significant and satisfies student expectations (Keller, 1983). It can be established by using language and examples familiar to the learner and relating the knowledge to future usefulness. Role playing and games that force students to think creatively and independently create relevance. Using analogies and visualization of real-world problems, providing examples of the importance of information to the students' careers, inviting guest lecturers who are experienced in the subject, and acting enthusiastically can also provide relevance. Research has shown students are most motivated by "interest in and perceived relevance of the material” (Gorhan and Christophel, 1992, p. 247).

Confidence can be instilled by creating incremental successes in the learning process, making success meaningful, and giving the learner control over their progress and assessment. Satisfaction is supported by methods that provide constructive feedback to the learner and provide examples of how the material can assist in real applications. It is also supported by an organized learning environment that empowers students and is closely related to confidence. Once confidence is established, satisfaction will follow if the learner is challenged. Creating learning goals that are attainable and in which the learner can demonstrate competency, especially in the classroom, instills both confidence and satisfaction.

\subsection{Problem Based Learning}

Problem-Based Learning (PBL) is a method of instruction that stresses an interactive hands-on approach to solve real-world problems. PBL uses openended context specific problems with no single correct answer. Students are encouraged to seek out the best tools and methodologies and seek creative ways to unstructured or semi-structured problems and to learn through exploration. 
Students work in self-directed collaborative groups and teachers assume the role of facilitators. The teacher's role is to provide direction and motivate the learner to inquiry through challenging questions and problems. Focus is on creative thinking whereby students apply their knowledge to new situations in order to solve unstructured problems and discover new and creative pathways to solutions (Hmelo-Silver and Barrows, 2006). PBL is thought to increase learner's motivation, improve problem-solving skills, and develop critical thinking (Margetson, 1994).

\subsection{Discovery Learning}

Discovery Learning (DL) is an inquiry-based approach to instruction that makes the learner primarily responsible for uncovering new knowledge through inquirybased instruction. Using problem-solving situations, the learner draws upon past knowledge and skills to construct new pathways to problem-solving in order to discover new facts and relationships. It is an interactive approach in which students grope with real-world problems performing activities that lead them to new knowledge and skills. DL recognizes the importance of mapping new information to the problems it can address (Bruner, 1967). As a result, the learner is more likely to retain the new knowledge and skills. DL encourages active engagement, motivates the student, and promotes creative and critical thinking.

A benefit of the ARCS model is that it provides explicit suggestions and is highly applicable for a course of instruction that is both skills-based and conceptual. PBL is also appropriate for a course that introduces computer forensics to accounting students. Accountants are accustomed to working in groups and are generally self-motivated. DL is useful where the students solve auditing problems using a selection of web-based tools they deem appropriate. PBL and DL both support the inquiry-based, problem-solving approach where the student is primarily responsible for acquiring skills and knowledge. In this environment, the teacher acts as facilitator, providing direction, tools and assignments and intervening when the student is not making sufficient progress or is confused about the learning outcomes.

\subsection{Audit Problems}

Students will be assigned audit problems that simulate the IT control problems that can be encountered by external, internal and IT auditors working with private and governmental organizations. The problems will reflect real-world assignments and provide the student the wherewithal to investigate using computer forensic tools in a logical and structured manner. Student responsibilities will include uncovering weak internal controls and instances of fraud. Assignments will include: establishing that the network system is secure, establishing that the network has anti-virus software, performing an inventory of system assets, establishing that the local host is secure, locating hidden files, erasing or wiping sensitive file space, creating check-sums, recovering passwords, recovering damaged files, encrypting files, checking file integrity, mapping ports 
to applications, and verifying IPv4 and MAC addresses. Working in groups, students will be responsible for identifying the correct audit approach and incorporating tools that support their analysis. They will present their findings based on the use of these tools. The instructor will introduce a sample of the tools in the classroom and use quizzes and in-class collaborative problem-solving to gain attention. Role and game playing and guest speakers will be used to support both attention and relevancy. The relevancy of the assignments will be explained to the students citing the usefulness to their own careers.

Individually, each student will be called upon to formally present the use of two of the forensic tools and discuss their investigative potential. Students will also be given short description of audit problems and be asked to determine which tools might be applicable. These exercises are expected to create active discussions and create confidence and satisfaction.

\subsection{Forensic Tools}

An annotated list of forensic tools that can be used by accountants in their audit investigations is shown in Appendix 1. Students will determine which of these tools are applicable to their assigned problems and show how they can be used in the investigation. Collaborative exercises involving specific tools and DOS commands will be assigned. The accompanying links are available at http://www.stpt.usf.edu/bayview/forensics/.

\section{HYPOTHESES AND METHODOLOGY}

Nine hypotheses are presented. The hypotheses are intended to reflect the students' interest in the subject and their perception of the class a priori and ex post and identify what curriculum design strategies are successful. First, it is theorized that accounting students will perceive computer forensic education as positively affecting their careers. The student's desire to pursue knowledge and skills in this area is important to classroom success. Thus,

H1: Graduate accounting students perceived interest in computer forensics will be positive.

Whereas many accounting subjects are basic to a successful career, computer forensics knowledge is not essential unless the student wishes to gain advanced certification or become an IT auditor. Otherwise, the class may lack relevance and students would not be motivated to take it. Students who are interested in IT auditing and gaining certification are expected to perceive the class as more relevant to their needs and display higher interest. Thus,

H2: Graduate accounting students perceived interest in computer forensics will be positively associated with the intention to acquire advanced certifications.

H3: Graduate accounting students perceived interest in computer forensics will be positively associated with the intention to become an IT 
auditor.

Students are expected to work interactively in groups identifying and acquiring the specific forensic tools they need to solve auditing problems. This approach is expected to support both concrete and abstract learning styles. Analysis of the audit problem and selection of appropriate tools would represent the abstract while application of the tools and analysis of the results would represent the concrete. As such, a majority of the students will express satisfaction with the exercises that involve forensic tools and will be successful in their selection and application.

H4: Graduate accounting students will be successful in the selection and application of web-based forensics tools to audit applications.

Curriculum design and pedagogical techniques based on the ARCS Motivational Model are expected to be associated with higher levels of attention, relevancy, confidence and satisfaction. Using the learning strategies in Table 1, it is expected that students' perceived levels for course outcomes will be higher where they perceive these techniques to be present and successfully applied. Thus,

H5: Graduate accounting students will indicate a positive association between the attention indicators and the indicators of course outcomes.

H6: Graduate accounting students will indicate a positive association between the relevancy indicators and the indicators of course outcomes.

H7: Graduate accounting students will indicate a positive association between the confidence indicators and the indicators of course outcomes.

H8: Graduate accounting students will indicate a positive association between the satisfaction indicators and the indicators of course outcomes.

Graduate accounting students are generally highly self-motivated and comfortable with abstract reasoning. Therefore, attention strategies are assumed to be of less importance. Because they are in a career that is in demand, have attained a high level of education, and are seeking an emphasis in an advanced field of study, it is assumed that confidence and satisfaction strategies will be of less importance. However, because graduate accounting students are under pressure to attain advanced certifications must have a fifth year in accounting to be a CPA, and are pursuing an MBA degree, time management is important to them and they are less likely to invest time in courses that are not on their career path. Therefore, relevancy strategies are expected to be more important in curriculum design. Thus,

H9: Graduate accounting students will indicate a higher positive association between the relevancy indicators and the indicators for course outcomes than for the other three design indicators of attention, confidence and satisfaction and the indicators for course outcomes. 


\begin{tabular}{|c|c|c|c|c|}
\hline Planned Learning Approach & A & $\mathbf{R}$ & C & $\mathbf{S}$ \\
\hline $\begin{array}{l}\text { Provide various and novel approaches to learning reflecting different } \\
\text { learning styles. }\end{array}$ & $\mathrm{X}$ & $\mathrm{X}$ & & \\
\hline Use multimedia in instruction and provide material in lecture and readings. & $\mathrm{X}$ & $\mathrm{X}$ & & \\
\hline Clearly state how students will be evaluated. & $\mathrm{X}$ & $\mathrm{X}$ & & \\
\hline $\begin{array}{l}\text { Base assignments on individual needs and provide examples based on } \\
\text { student's experience and goals. }\end{array}$ & $\mathrm{X}$ & $\mathrm{X}$ & & \\
\hline $\begin{array}{l}\text { Provide clearly stated weekly goals and explain why it is important to } \\
\text { achieve these goals. }\end{array}$ & $\mathrm{X}$ & $\mathrm{X}$ & & \\
\hline Provide immediacy with the students. & $\mathrm{X}$ & & $\mathrm{X}$ & \\
\hline Allow flexible approaches to problem solving. & $\mathrm{X}$ & & & $\mathrm{X}$ \\
\hline $\begin{array}{l}\text { Make personal contact with each learner to insure assignments and } \\
\text { modalities are reflecting personal needs. }\end{array}$ & $\mathrm{X}$ & & & $\mathrm{X}$ \\
\hline Assign a group project and encourage collaborative work. & $\mathrm{X}$ & & & $\mathrm{X}$ \\
\hline $\begin{array}{l}\text { Collect student demographic information on first day of class and tailor } \\
\text { assignments to learning styles. }\end{array}$ & & $\mathrm{X}$ & $\mathrm{X}$ & \\
\hline Provide assignments that reflect real-world forensic auditing tasks. & & $\mathrm{X}$ & $\mathrm{X}$ & \\
\hline Provide a comprehensive set of forensic tools and instructions. & & $\mathrm{X}$ & $\mathrm{X}$ & \\
\hline $\begin{array}{l}\text { Provide early assignments that reflect entry experience and provide student } \\
\text { some control over outcome. }\end{array}$ & & $\mathrm{X}$ & $\mathrm{X}$ & \\
\hline Provide concrete and constructive feedback on progress in a timely manner. & & & $\mathrm{X}$ & $\mathrm{X}$ \\
\hline Establish guidance on how students can successfully attain goals. & & & $\mathrm{X}$ & $\mathrm{X}$ \\
\hline Provide ongoing technical support in a timely fashion. & & & $\mathrm{X}$ & $\mathrm{X}$ \\
\hline \multicolumn{5}{|c|}{ Where A-Attention, R-Relevance, C-Confidence, S-Satisfaction (Adapted from Chyung, 2001.) } \\
\hline
\end{tabular}

\subsection{Data Collection and Analysis}

Data was collected from graduate accounting students taking the class Computer Forensics for Accountants at the University of South Florida St. Petersburg. This class is offered as part of a four-course emphasis on fraud accounting in the MBA program. Data was collected twice: on the first day and last day of class. Questions measured the precourse (a priori) and postcourse (ex post) attitudes for Attention, Confidence, Relevance and Satisfaction. The two research instruments are shown in Appendix 2. Analysis involved correlation of the indicators to test the hypotheses. Analysis was performed using the indicators shown in Table 2 that are taken from the post course survey (Appendix 2.b). 


\begin{tabular}{|c|c|c|c|c|c|c|}
\hline $\begin{array}{l}\text { Survey } \\
\text { Qstn. }\end{array}$ & Measures / Indicators & A & $\mathbf{R}$ & C & $\mathbf{S}$ & CO \\
\hline 1 & The course goals were explicitly stated & $\mathrm{X}$ & & & & \\
\hline 2 & $\begin{array}{l}\text { I understood why the course goals were } \\
\text { important to my career }\end{array}$ & & $\mathrm{X}$ & & & \\
\hline 3 & The course evaluation methodology was clear & $\mathrm{X}$ & & & & \\
\hline 4 & $\begin{array}{l}\text { A variety of classroom teaching techniques } \\
\text { were used }\end{array}$ & $\mathrm{X}$ & & & & \\
\hline 5 & PowerPoint slides were interesting and useful & $\mathrm{X}$ & & & & \\
\hline 6 & $\begin{array}{l}\text { The professor used a variety of methods of } \\
\text { instruction }\end{array}$ & & $\mathrm{X}$ & & & \\
\hline 7 & The professor related well to the class & & & $\mathrm{X}$ & & \\
\hline 8 & $\begin{array}{l}\text { The professor showed interest in my learning } \\
\text { progress }\end{array}$ & & & & $\mathrm{X}$ & \\
\hline 9 & The professor responded to my emails promptly & & & & $\mathrm{X}$ & \\
\hline 10 & $\begin{array}{l}\text { The professor engaged the class in active } \\
\text { discussion }\end{array}$ & & $\mathrm{X}$ & & & \\
\hline 11 & $\begin{array}{l}\text { The professor provided assistance when I had } \\
\text { questions }\end{array}$ & & & $\mathrm{X}$ & & \\
\hline 12 & $\begin{array}{l}\text { I felt comfortable asking questions and } \\
\text { contributing in-class }\end{array}$ & & & $\mathrm{X}$ & & \\
\hline 13 & $\begin{array}{l}\text { The group assignment helped me to master the } \\
\text { material }\end{array}$ & & & & $\mathrm{X}$ & \\
\hline 14 & The professor encouraged collaborative work & & & & $\mathrm{X}$ & \\
\hline 15 & $\begin{array}{l}\text { Grading of assignments and exams was fair and } \\
\text { clear }\end{array}$ & & & $\mathrm{X}$ & & \\
\hline 16 & $\begin{array}{l}\text { I felt in control of the material and my success } \\
\text { in this class }\end{array}$ & & $\mathrm{X}$ & & & \\
\hline 17 & $\begin{array}{l}\text { I found the guest speakers to be valuable and } \\
\text { interesting }\end{array}$ & & $\mathrm{X}$ & & & \\
\hline 18 & $\begin{array}{l}\text { I am comfortable with computer tools in } \\
\text { general }\end{array}$ & & & & & $\mathrm{X}$ \\
\hline 19 & The course met or exceeded my expectations & & & & & $\mathrm{X}$ \\
\hline 20 & I learned new forensic skills in this class & & & & & $\mathrm{X}$ \\
\hline 21 & $\begin{array}{l}\text { I believe IT knowledge and skills are important } \\
\text { to my career }\end{array}$ & & & & & $\mathrm{X}$ \\
\hline 22 & $\begin{array}{l}\text { I learned relevant forensic accounting } \\
\text { knowledge in this class }\end{array}$ & & & & & $\mathrm{X}$ \\
\hline 23 & $\begin{array}{l}\text { The web-based forensic tools were important } \\
\text { learning aids }\end{array}$ & & & & & $\mathrm{X}$ \\
\hline 24 & $\begin{array}{l}\text { Applying the forensic tools to audit problems } \\
\text { increased my understanding of the forensic } \\
\text { techniques }\end{array}$ & & & & & $\mathrm{X}$ \\
\hline 25 & I would recommend this class to a friend & & & & & $\mathrm{X}$ \\
\hline & Mean Value $(\mathrm{n}=19)$ & 5.5 & 5.9 & 5.8 & 5.8 & 6.1 \\
\hline \multicolumn{7}{|c|}{$\begin{array}{l}\text { Where A-Attention, R-Relevance, C-Confidence, S-Satisfaction, } \\
\text { CO-Course Outcomes }\end{array}$} \\
\hline
\end{tabular}


Each indicator was measured by at least four survey questions. Measures were collected for each of the four motivational indicators and course outcomes. Measuring the association between the indicators and course outcomes was intended to provide insight in the ability of the curriculum to impact learning outcomes.

\subsection{Results of Analysis}

Pearson product moment correlations were calculated to determine the strength of the relationships between the four motivational indicators and course outcomes. Pearson product moment correlates measure the linear relationships between two variables. Results, shown in Table 3, indicate moderate to strong positive relationships $(r>.50)$ and statistically significant $(p=.01)$. Thus we can state that each of the indicators has a moderate to strong linear relationship with course outcomes. These same relationships existed between the indicators.

Support for the nine hypotheses is shown in Table 4. All of the hypotheses were supported. The overall mean of 6.1 or 87 percent for the eight measures of course outcomes was used to support H1. While all of the students indicated an intention to acquire an advanced certification in accounting an unexpectedly high amount of 85 percent indicated a possible interest in pursuing a certification as an IT auditor. These results were used to support $\mathrm{H} 2$ and $\mathrm{H} 3$.

The survey question "Applying the forensic tools to audit problems increased my understanding of the forensic techniques" was answered with a mean response of 6.15 or and 88 percent response. This was used to support H4. The high correlates ( $\mathrm{r}$ ranged from .65 to .88 ) between the four indicators of motivation and course outcomes supported H5, H6, H7, and H8. Finally, the slightly stronger value for the relationship between relevancy and course outcomes was used to support H9.

\begin{tabular}{|c|r|r|r|r|r|}
\hline Indicator & \multicolumn{1}{|c|}{ A } & \multicolumn{1}{c|}{$\mathbf{R}$} & \multicolumn{1}{c|}{ C } & \multicolumn{1}{c|}{ S } & CO \\
\hline $\mathbf{A}$ & 1 & & & & \\
\hline $\mathbf{R}$ & 0.900 & 1 & & & \\
\hline $\mathbf{C}$ & 0.627 & 0.798 & 1 & & \\
\hline $\mathbf{S}$ & 0.880 & 0.948 & 0.836 & 1 & \\
\hline $\mathbf{C O}$ & 0.794 & 0.877 & 0.645 & 0.864 & 1 \\
\hline Table 3. Correlations of Indicators \\
$\begin{array}{l}\text { A-Attention, R-Relevancy, C-Confidence, S-Satisfaction } \\
\text { CO-Course Outcomes (All significant at .01 level) }\end{array}$ \\
\hline
\end{tabular}




\begin{tabular}{|c|c|c|}
\hline Hypothesis & Supported & Rationale \\
\hline $\begin{array}{l}\text { H1: Graduate accounting students perceived } \\
\text { interest in computer forensics will be positive. }\end{array}$ & Yes & $\begin{array}{l}\text { Course outcomes } \\
=87 \%\end{array}$ \\
\hline $\begin{array}{l}\text { H2: Graduate accounting students perceived } \\
\text { interest in computer forensics will be positively } \\
\text { associated with the intention to acquire advanced } \\
\text { certifications. }\end{array}$ & Yes & $\begin{array}{l}100 \% \text { indicate an } \\
\text { interest in a CPA. }\end{array}$ \\
\hline $\begin{array}{l}\text { H3: Graduate accounting students perceived } \\
\text { interest in computer forensics will be positively } \\
\text { associated with the intention to become an IT } \\
\text { auditor. }\end{array}$ & Yes & $\begin{array}{l}85 \% \text { indicate } \\
\text { interest in IT Audit } \\
\text { Certification. }\end{array}$ \\
\hline $\begin{array}{l}\text { H4: Graduate accounting students will be } \\
\text { successful in the selection and application of } \\
\text { web-based forensics tools to audit applications. }\end{array}$ & Yes & $\begin{array}{l}88 \% \text { indicate } \\
\text { ability to use } \\
\text { forensic tools for } \\
\text { the applications. }\end{array}$ \\
\hline $\begin{array}{l}\text { H5: Graduate accounting students will indicate a } \\
\text { positive association between the attention } \\
\text { indicators and the indicators of course outcomes. }\end{array}$ & Yes & Correlation $\mathrm{r}=.79$ \\
\hline $\begin{array}{l}\text { H6: Graduate accounting students will indicate a } \\
\text { positive association between the relevancy } \\
\text { indicators and the indicators of course outcomes. }\end{array}$ & Yes & Correlation $r=.88$ \\
\hline $\begin{array}{l}\text { H7: Graduate accounting students will indicate a } \\
\text { positive association between the confidence } \\
\text { indicators and the indicators of course outcomes. }\end{array}$ & Yes & Correlation $r=.65$ \\
\hline $\begin{array}{l}\text { H8: Graduate accounting students will indicate a } \\
\text { positive association between the satisfaction } \\
\text { indicators and the indicators of course outcomes. }\end{array}$ & Yes & Correlation $r=.86$ \\
\hline $\begin{array}{l}\text { H9: Graduate accounting students will indicate a } \\
\text { higher positive association between the relevancy } \\
\text { indicators and the indicators for course outcomes } \\
\text { than for the other three design indicators of } \\
\text { attention, confidence and satisfaction and the } \\
\text { indicators for course outcomes. }\end{array}$ & Yes & $\begin{array}{l}\text { Highest } \\
\text { Correlation }\end{array}$ \\
\hline \multicolumn{3}{|l|}{ Table 4. Support for Hypotheses } \\
\hline
\end{tabular}

\section{DISCUSSION}

Computer forensics has become increasingly important to accountants and to the accounting profession. Educating accountants in the use of forensic tools is essential but difficult. Students perceive forensic tools as complex and find there are no firm guidelines telling them what tools best fit what audit problems. Consequently, the education in forensics is much less structured than the typical accounting course. As such, the instructor must motivate the students to learn in an interactive mode that fits various learning styles. An approach to curriculum design is to develop learning strategies that will motivate students with different 
learning styles. This paper presents that methodology in an attempt to improve the ability of accounting students to acquire knowledge and skills in computer forensics and learn to apply it to problems that parallel real-world situations. A set of over 50 forensic tools, mostly web-based, are also presented for use in solving realistic audit problems. Based upon a survey of 19 graduate accounting students, nine hypotheses were tested and supported showing that motivational practices are positively associated with course outcomes.

\section{REFERENCES}

AICPA, Professional Standards, Vol. 1, AU section 316, Consideration of Fraud in a Financial Statement Audit. Retrieved from: http://www.aicpa.org/download/members/div/auditstd/AU-00316.PDF

Bruner, J.S. (1967) On knowing: Essays for the left hand. Cambridge, Mass: Harvard University Press.

Buckoff, T.A. and Schrader, R.W. (2000) The Teaching of Forensic Accounting. Journal of Forensic Accounting, Vol. 1 (1), pp. 135-146.

Cerullo, M. and Cerullo, M. J. (2005) How the New Standards and Regulations Affect an Auditor's Assessment of Compliance with Internal Controls. Retrieved from: www,isaca.org/jonline. February 10, 2009.

Cangemi, M. P. (2000) (ed.) What Recruiters and Staffing Agencies Say about Trends in IS Auditing, Information Systems Control Journal, Vol. 5, pp. 43-45.

Chyung, Y. (2001) Systemic and Systematic Approaches to Reducing Attrition Rates in Online Higher Education, American Journal of Distance Education, Vol. 15 (3), pp. 36-49.

COSO (Committee on Sponsoring Organizations, 1992) Retrieved January 10, 2010 from: http://www.sox-online.com/coso cobit coso framework.html

Crumbley, D.L, Heitger, L.E. and Smith, G.S. (2007) Forensic and Investigative Accounting, $3^{\text {rd }}$ ed. CCH Incorporated, Chicago, IL.

Davis, C., Schiller, M. and Wheeler, K. (2007) IT Auditing: Using Controls to Protect Information Assets, McGraw-Hill, New York.

Gorham, J., and Christophel, D. M. (1992) Students’ Perceptions of Teacher Behaviors as Motivating and Demotivating Factors in College Classes. Communication Quarterly, Vol. 40, pp. 239-252.

Hmelo-Silver, C. E. \& Barrows, H. S. (2006) Goals and strategies of a problem-based learning facilitator, Interdisciplinary Journal of Problem-based Learning, Vol. 1, pp. 21-39.

Hoffman, T. (2004) IT Auditors Coveted, Hard to Find, Computerworld, Vol. 38 (18), pp. 1-16.

ITGI (2004) IT Control Objectives for Sarbanes-Oxley. www.isaca.org/sox. 
January 8, 2009.

Kearns, G. S. (2006) A Curriculum for Teaching Information Technology Investigative Techniques for Auditors, Journal of Digital Forensics, Security and Law, Vol. 1 (4), pp. 9-28.

Kearns, G. S. (2009) Graduate Accounting Students' Perception of IT Forensics: A Multi-Dimensional Analysis, Journal of Digital Forensics, Security and Law, Vol. 4 (1), pp. 5-37.

Keller, J. M. (1983) Motivational Design of Instruction. In C. M. Reigeluth (ed.), Instructional Design Theories: An Overview of Their Current Status, pp. 383-434.

Keller, J. M. (1987) Development and use of the ARCS model of motivational design, Journal of Instructional Development, Vol. 10 (3), pp. 2-10.

Li, S., Huang, S. and Lin, Y. G. (2007) Developing a Continuous Auditing Assistance System Based on Information Process Models. The Journal of Computer Information Systems, Vol. 48 (1), pp. 2-13.

Margetson, D. (1994) Current Educational Reform and the Significance of Problem-Based Learning, Studies in Higher Education, Vol. 19(1), pp. 5-19.

Merhout, J. W. and Buchman, S. E. (2007) Requisite Skills and Knowledge for Entry-level IT Auditors. Journal of Information Systems Education, Vol. 18 (4), pp. 469-477.

Rezaee, Z. and Crumbley, L. (2007) The Role of Forensic Auditing Techniques in Restoring Public Trust and Investor Confidence in Financial Information, Forensic Examiner, March 22, 2007. Retrieved from: http://goliath.ecnext.com/coms2/gi 0199-6376587/The-role-of-forensicauditing.html, January 10, 2010.

Sarbanes-Oxley Act of 2002 (SOX, 2002) Retrieved from http://www.sec.gov/about/laws/soa2002.pdf , January 10, 2010.

Statement on Auditing Standards (SAS) No. 99, Consideration of Fraud in a Financial Statement Audit (AICPA, Professional Standards, Vol. 1, AU Sec. 316.50).

Sumners, G. E. and Soileau, J. S. (2008) Addressing Internal Audit Staffing Challenges, Information Systems Management, Vol. 25 (2), pp. 3-11.

Van Grembergen, W., De Haes, S, and Moons, J. (2005) Linking Business Goals to IT Goals and COBIT Processes, Information Systems Control Journal, Vol. 4, pp. 18-21. 


\section{APPENDIX 1}

\section{AnNotated List OF CoMmands}

Most of the following tools are available free online. Most require download but some can be run online. All links are provided in a section following the descriptions. Information for downloading and using each tool is provided online. The accompanying links are available at http://www.stpt.usf.edu/bayview/forensics/

\section{DOS Commands}

Disk Operating System commands are useful for determining the IP and MAC address and examining activity on the computer ports. Some commands offer a variety of switches for providing added information. A full list of commands is available on the web. These commands are typed in the command prompt window that is accessible in the Windows operating system in the Accessories folder.

ipconfig /all - provides system information including the IP and MAC addresses

ping [url] - sends a packet to the url to determine if the address is alive

tracert [url] - lists all hops between the local and the destination computer

netstat -b - lists all open ports and the program that opens each one

nslookup [url] - lists all IP addresses associated with the url

psinfo - list system information, including installed service packs and drive information

bootcfg /query - lists contents of boot.ini file

fport - view of processes mapped to ports

\section{Free Web Tools}

Autoruns - Windows utility shows you what programs are configured to run during system bootup or login, and shows you the entries in the order Windows processes them. These programs include ones in your startup folder, Run, RunOnce, and other Registry keys.

BgInfo - Assists administrators who manage multiple computers. It automatically displays relevant information about a Windows computer on the desktop's background, such as the computer name, IP address, service pack version, and more. You can edit any field as well as the font and background colors, and can place it in your startup folder so that it runs every boot, or even configure it to display as the background for the logon screen.

CCleaner - Used to securely delete any browsing history including temp files, 
cookies and browsing history. Can also wipe your Recycle Bin, Clipboard and memory. For the truly security conscious and paranoid.

Cookies - To view and remove cookies in Internet Explorer, click Tools/Internet Options and in Browsing History click Settings and View Files (these are temporary files). Sort and view cookies (type is Text Document). You may delete cookies but may lose some functionality if you have stored passwords.

Disk Investigator ${ }^{\circledR}$ - - Disk Investigator helps you to discover all that is hidden on your computer hard disk. It can also help you to recover lost data. Display the true drive contents by bypassing the operating system and directly reading the raw drive sectors. View and search raw directories, files, clusters, and system sectors. Undelete previously deleted files. Verify the effectiveness of file and disk wiping programs.

EasyCrypto ${ }^{\circledR} \quad$ - You can build self-extracting encrypted and compressed archives and send them to others. The only thing a recipient needs to extract the encrypted files is the correct password. The decrypting and decompressing engine is encapsulated inside the archive. After you encrypt files, EasyCrypto securely wipes originals automatically.

Eraser ${ }^{\circledR}$ - Effectively wipes disk areas containing previously deleted files so they cannot be recovered. Can be used for a single file or multiple files.

Forensic Toolkit ${ }^{\circledR}$ - Contains several Win32 Command line tools that can help you examine the files on a NTFS disk partition for unauthorized activity. Can identify unauthorized changes to files and hidden files. Provided by Foundstone (a division of McAfee).

Galleta V 1.0® - Supports investigation of cookie files by importing them into Excel for examination. Provided by Foundstone (a division of McAfee).

HashCalc - Checksum calculator with a simple dialog-size interface that creates 13 common checksum algorithms. A checkbox next to each makes it easy to indicate whether the app will calculate the file checksum for that algorithm.

Hidden Files - For Windows, go to Control Panel/Appearance and Personalization/Folder Options and check Show Hidden Files, Folders and Drive.

John the Ripper ${ }^{\circledR}(\mathrm{JtR})$ and FS Crack - Password auditing tool. JtR is a command driven program and FS Crack is a graphical user interface (GUI) frontend for JtR and includes a user guide.

K-9® - Content filtering software for home computers and based on the same technology used in industry. Allows parents to control what content is accessible. Internet content is divided into 60 distinct categories. Administrators can configure the software to block or allow specific categories.

LCP ${ }^{\circledR}$ - Password auditing tool with graphical front-end. Individuals and administrators can use it to test the strength of their own passwords. 
Microsoft ${ }^{\circledR}$ Windows ${ }^{\circledR}$ Malicious Software Removal Tool - computers for and helps remove infections by specific, prevalent malicious software-including Blaster, Sasser, and Mydoom. When the detection and removal process is complete, the tool displays a report describing the outcome, including which, if any, malicious software was detected and removed. The tool creates a log file named mrt.log in the \%WINDIR\%ldebug folder.

Microsoft ${ }^{\circledR}$ Windows ${ }^{\circledR}$ Computer Investigation Guide for Windows Provides a computer investigation model as well as process and best practice information. The guide also provides a fictitious example of an investigation that involves unauthorized access to confidential information. An appendix provides information about how to prepare for computer investigations, sample worksheets, contact information for reporting different types of computer-related crimes to appropriate law enforcement agencies, and lists of useful tools.

Ophcrack ${ }^{\circledR}$ - A stronger password recovery tool for alphanumeric passwords. Takes considerably longer to download but valuable for tougher recoveries.

Fgdump - Utility for dumping passwords on a Windows system. The user must have administrator access rights. Once dumped, the passwords can be cracked with JtR.

Free Word and Excel Recovery ${ }^{\circledR}$ - A tool for recovering passwords to Word, Excel and Access files that have been password protected. Great for security minded individuals who have misplaced their passwords.

Nessus ${ }^{\circledR}$ - Vulnerability scanner commonly used today by many companies and government organizations. Requires installation of plug-ins. Scans are very thorough. configuration auditing, asset profiling, sensitive data discovery and vulnerability analysis of your security posture. Performs configuration auditing, asset profiling, sensitive data discovery and vulnerability analysis of your security posture. Always run locally unless you have permission to scan the network.

Network Locator - A utility that approximates and displays the geophysical location of your network address on a Google Map. Not a download.

Nmap - An open source tool for network exploration and security auditing designed to rapidly scan large networks but can be used on single hosts. Displays what hosts are available on the network, what services (application name and version) those hosts are offering, what operating systems (and OS versions) they are running, what type of packet filters/firewalls are in use, and other characteristics. Commonly used for security audits, and routine tasks such as network inventory, managing service upgrade schedules, and monitoring host or service uptime.

Paraben ${ }^{\circledR} 2.0$ - Allows you to mount your forensic image and explore it as though it were a drive on your machine while preserving the forensic nature of your evidence. In fact, P2 eXplorer is one of the only programs that mounts 
images as logical and physical disks. This means all the deleted, slack, and unallocated space is accessible. An image isn't just mounted to view logical files; it is mounted as an actual bit-stream image, preserving unallocated, slack, and deleted data.

Pasco ${ }^{\circledR}$ - Supports investigative research of browsing activity by examination of Internet Explorer cache files (index.dat files). Parses data for input into spreadsheet programs for easier analysis. Provided by Foundstone (a division of McAfee).

Phone Number GeoLocator - Provides the geographical location of U.S. phone numbers. Not a download.

Proxify - A web-based anonymous proxy service which allows you to surf the Web privately and securely. There is no software to install. Just enter a URL in the online form. Proxify hides your IP address and the encrypted connection prevents monitoring of your network traffic.

Pwchecker - Evaluates the strength of your current passwords. Provides detailed information about problems that make the password less secure.

Pwdump - Dumps Windows password hashes into a format usable by nearly all password crackers. Different versions are available. Some prefer fgdump.

Recuva ${ }^{\circledR}$ - Recovers files from hard drives, external drives (USB drives, etc.) and memory cards. Recuva can even undelete files from your iPod!

$\operatorname{Refog}{ }^{\circledR}$ - Described as being impossible to be seen or removed by your teenage kids or the spouse. Refog is a surveillance tool that collects all key activity on the computer. A freeware is available.

Reverse IP Domain Check - Enter a domain name or IP address and search for other sites known to be hosted on that same web server. A fast and easy way to find the IPv4 address for a domain name. Not a download.

Sam Spade - A network suite of tools including one that will help track unsolicited email.

Sentinel 2.2.1 ${ }^{\circledR} \quad$ - Advanced file integrity checker audits the system folder (as well as up to 20 other folders) for the slightest file changes and/or additions. If any files fail the integrity check, the anti-virus/trojan program will be notified. Has been deployed at both the enterprise and government sectors to ensure system compliance and security. Easy to use GUI format.

Shields Up ${ }^{\circledR} \quad$ - Free Internet vulnerability profiling and provides your IPv4 address. Easy to use and provides a fast graphical display of the status for all common ports.

Show Hidden Files - Security utility designed to find password protected files of various types - .zip, .rar, Word .doc, Excel .xls, PGP disks. 30 day free trial version. 
ShowWin - Identify hidden windows, force windows to stay on top and, in special cases, identify passwords behind those asterisks (******).Provided by Foundstone (a division of McAfee).

Snare for Windows ${ }^{\circledR} \quad$ - Can be used to filter and organize events from Windows Event Viewer and custom rank events by level of severity. Works remotely and makes administration more efficient and effective.

Superscan $4 \AA \quad$ - Identifies which ports on the computer are open and what programs opened them. Too many open ports makes it easier for hackers to infiltrate your computer. After an application has closed, the associated port should also close. Certain ports are automatically associated with specific applications (Port 80 - Web, Port 20 - FTP, Port 25 - Email, etc.). Caution: You can used Superscan on your own computer but do not scan networks without alerting the network administrator who will be monitoring your own activity. This could appear to be a hacker seeking unprotected ports. Provided by Foundstone (a division of McAfee).

Sysinternals Suite - A large bundle of troubleshooting utilities have been rolled up into a single suite of tools. This file contains the individual troubleshooting tools and help files. A must.

Tcpview - A Windows program that will show you detailed listings of all TCP and UDP endpoints on your system, including the local and remote addresses and state of TCP connections.

Trout ${ }^{\circledR}$ - A tracert and Whois program that can identify hosts on the route to a destination computer. Provided by Foundstone (a division of McAfee).

Vision V 1.0 - Lists all open ports, maps them to their applications and provides supplementary detailed information for analysis of activity. Interrogates ports and identifies possible probes. Provided by Foundstone (a division of McAfee).

Web Sleuth ${ }^{\circledR}$ - Sleuth is a Web Application Assessment Tool. It can be used to great effect by both auditors and developers alike to debug/analyze Web Applications for function \& security. 20 day free trial version.

WhoIs Lookup Tool - Performs a WHOIS lookup to provide information such as the owner of a domain name or an IP address on the Internet. This tool is limited to .com, .net, and .edu domains. Not a download.

Windows Event Viewer ${ }^{\circledR}$ - Organizes logged events on Windows OS. Go to Control Panel/Administrative Tools/Local Security Policy/Audit Policy and click Audit Account Logon Events and select both Success and Failure. For more detail go to the Microsoft page for this utility.

Wireshark Packet Sniffer - Intercepts packets on the network including those that are not yours. Primarily used by network administrators for monitoring network activity, they are also used by hackers for intrusion into private files. Download Wireshark I for an introduction. You must also download WinPCap to 
actually capture the network packets. Wireshark II allows you to filter out unwanted packets, and Wireshark III can be used to intercept email. Caution: Do not use these without alerting the network administrator who will be monitoring your own activity. These tools should never be used to capture packets that do not belong to the user.

\section{Comercial Software for Forensic Analysis}

Anonymizer Anonymous Surfing - Hides your IP address, protecting your privacy and securing your identity. Online snoops are unable to track the sites you visit and build profiles on your Internet activities. 30 day free trial version.

EnCase ${ }^{\circledR}$ - Utility to acquire data in a forensically sound manner, using software that has been accepted in courts worldwide. Limit incident impact and eliminate system downtime with immediate response capabilities. Efficiently collect only potentially relevant data upon eDiscovery requests.

Hide the IP 2010® - Allows user to hide the IP address to anonymize web activity.

OnTrack Data Recovery ${ }^{\circledR}$ - Commercial data recovery including disk, tape, email, all file formats and operating systems, lost and damaged files.

Phone Search Central - Not a web tool but a web-based investigative service that guarantees results. Specializes in the reversal of unlisted/non published cellular and landline telephone numbers throughout USA, Canada, Great Britain and Ireland. Locates telephone number information from active or disconnected numbers, mobile phones, home phones, unlisted numbers, US based phone numbers and Canadian phone numbers. Any kind of phone number can be reversed to its owner.

SafeBack - An industry standard self-authenticating computer forensics tool that is used to create evidence grade backups of hard drives. Creates bit-stream backup files of hard disks or a mirror-image copy of an entire hard disk drive or partition. The image files cannot be altered or modified to alter the reproduction.

Spector 360® - A surveillance tool that records web sites visited, emails sent and received, chats and instant messages, keystrokes typed, files transferred, documents printed and applications run. Shows exact visual detail employee online activities. Monitors web and computer activities from each of your employees, feeds that information into a database and provides you with more than 50 built-in reports. A lower-priced version is available for home use. All employees should be aware of the detail that employers can amass for possible use in a theft-of-services suit. Site includes informative demos. 


\title{
APPENDIX 2.A Pre Course Survey
}

\author{
Graduate Accounting Student PreCourse IT InTERest SurVey
}

Name Last First

Instructions: The purpose of this survey is to gather information that will allow your professor and the Program of Accountancy to make better informed choices about the materials included in the curriculum. Your individual answers are confidential and will not be made available to anyone other than the professor. Under no circumstances will an individual student's responses be identified or used as part of his or her grade. Please answer all questions as accurately as possible.

Do you plan to pursue advanced certifications such as a CPA, CMA, or CIA?

Would you consider pursuing a certification as an IT Auditor? $\quad$ YES NO MAYBE Have you taken the course in Fraud Accounting?

YES NO

Have you taken the course in Forensic Accounting?

YES NO

\begin{tabular}{|c|c|c|c|c|c|c|c|c|}
\hline \multicolumn{9}{|c|}{ Circle the number that best describes your level where $1=$ Low, $4=$ Neutral, $7=$ High } \\
\hline 1 & I prefer lectures using PowerPoint presentations & 1 & 2 & 3 & 4 & 5 & 6 & 7 \\
\hline 2 & I prefer in-class discussions & 1 & 2 & 3 & 4 & 5 & 6 & 7 \\
\hline 3 & I prefer working independently & 1 & 2 & 3 & 4 & 5 & 6 & 7 \\
\hline 4 & I prefer working in a group & 1 & 2 & 3 & 4 & 5 & 6 & 7 \\
\hline 5 & I prefer in-class problem solving & 1 & 2 & 3 & 4 & 5 & 6 & 7 \\
\hline 6 & I prefer active participation in class & 1 & 2 & 3 & 4 & 5 & 6 & 7 \\
\hline 7 & I prefer learning material that has immediate application & 1 & 2 & 3 & 4 & 5 & 6 & 7 \\
\hline 8 & I am comfortable with abstract material & 1 & 2 & 3 & 4 & 5 & 6 & 7 \\
\hline 9 & I need to know how the material is relevant to my career & 1 & 2 & 3 & 4 & 5 & 6 & 7 \\
\hline 10 & $\begin{array}{l}\text { I prefer to approach problem-solving in a structured } \\
\text { manner }\end{array}$ & 1 & 2 & 3 & 4 & 5 & 6 & 7 \\
\hline 11 & I need constant feedback on my performance & 1 & 2 & 3 & 4 & 5 & 6 & 7 \\
\hline 12 & I generally have difficulty in setting up problem solutions & 1 & 2 & 3 & 4 & 5 & 6 & 7 \\
\hline 13 & I enjoy learning new skills & 1 & 2 & 3 & 4 & 5 & 6 & 7 \\
\hline 14 & I can usually learn a subject by reading about it & 1 & 2 & 3 & 4 & 5 & 6 & 7 \\
\hline 15 & I learn best in a highly structured environment & 1 & 2 & 3 & 4 & 5 & 6 & 7 \\
\hline 16 & $\begin{array}{l}\text { I value the opinions of my classmates on the subject } \\
\text { material }\end{array}$ & 1 & 2 & 3 & 4 & 5 & 6 & 7 \\
\hline 17 & I am comfortable with computer tools in general & 1 & 2 & 3 & 4 & 5 & 6 & 7 \\
\hline 18 & I enjoy learning about computer tools & 1 & 2 & 3 & 4 & 5 & 6 & 7 \\
\hline 19 & $\begin{array}{l}\text { I believe IT knowledge and skills are important to my } \\
\text { career }\end{array}$ & 1 & 2 & 3 & 4 & 5 & 6 & 7 \\
\hline 20 & $\begin{array}{l}\text { I believe computer forensics knowledge is important to } \\
\text { my career }\end{array}$ & 1 & 2 & 3 & 4 & 5 & 6 & 7 \\
\hline \multicolumn{9}{|c|}{$\begin{array}{l}\text { Circle the number that best describes your level of knowledge or skill where } 1=\text { None, } 7= \\
\text { Very High }\end{array}$} \\
\hline 19 & MS Windows Operating System & 1 & 2 & 3 & 4 & 5 & 6 & 7 \\
\hline 20 & MS Windows Word, PowerPoint, Excel & 1 & 2 & 3 & 4 & 5 & 6 & 7 \\
\hline 21 & Web-based computer utilities & 1 & 2 & 3 & 4 & 5 & 6 & 7 \\
\hline 22 & Accounting Software Packages (any) & 1 & 2 & 3 & 4 & 5 & 6 & 7 \\
\hline 23 & Financial auditing & 1 & 2 & 3 & 4 & 5 & 6 & 7 \\
\hline 24 & Forensic auditing & 1 & 2 & 3 & 4 & 5 & 6 & 7 \\
\hline
\end{tabular}




\section{APPENDIX 2.B Post Course Survey}

\section{Graduate Accounting Student PreCourse IT InTerest Survey}

Do NOT write your name on this form. This survey is anonymous.

Instructions: The purpose of this survey is to gather information that will allow your professor and to make better informed choices about the materials included in the curriculum. All responses are completely anonymous. Please answer all questions as accurately as possible. If a question does not pertain to your classroom experience, leave it blank.

$\begin{array}{lllll}\begin{array}{l}\text { Do you plan to pursue advanced certifications such as a CPA, } \\ \text { CMA, or CIA? }\end{array} & \text { YES } & \text { NO } & \text { MAYBE } \\ \text { Would you consider pursuing a certification as an IT Auditor? } & \text { YES } & \text { NO } & \text { MAYBE } \\ \begin{array}{l}\text { Have you taken the course in Fraud Accounting? } \\ \text { Have you taken the course in Forensic Accounting? }\end{array} & \text { YES } & \text { NO } & \\ \end{array}$

\begin{tabular}{|c|c|c|c|c|c|c|c|c|}
\hline \multicolumn{3}{|c|}{$\begin{array}{l}\text { Circle the number that best describes your level of agreement where } \\
=\text { High }\end{array}$} & \multicolumn{6}{|c|}{1 = Low, 4 = Neutral, 7} \\
\hline 1 & The course goals were explicitly stated & 1 & 2 & 3 & 4 & 5 & 6 & 7 \\
\hline 2 & $\begin{array}{l}\text { I understood why the course goals were important to } \\
\text { my career }\end{array}$ & 1 & 2 & 3 & 4 & 5 & 6 & 7 \\
\hline 3 & The course evaluation methodology was clear & 1 & 2 & 3 & 4 & 5 & 6 & 7 \\
\hline 4 & A variety of classroom teaching techniques were used & 1 & 2 & 3 & 4 & 5 & 6 & 7 \\
\hline 5 & PowerPoint slides were interesting and useful & 1 & 2 & 3 & 4 & 5 & 6 & 7 \\
\hline 6 & The professor used a variety of methods of instruction & 1 & 2 & 3 & 4 & 5 & 6 & 7 \\
\hline 7 & The professor related well to the class & 1 & 2 & 3 & 4 & 5 & 6 & 7 \\
\hline 8 & The professor showed interest in my learning progress & 1 & 2 & 3 & 4 & 5 & 6 & 7 \\
\hline 9 & The professor responded to my emails promptly & 1 & 2 & 3 & 4 & 5 & 6 & 7 \\
\hline 10 & The professor engaged the class in active discussion & 1 & 2 & 3 & 4 & 5 & 6 & 7 \\
\hline 11 & The professor provided assistance when I had questions & 1 & 2 & 3 & 4 & 5 & 6 & 7 \\
\hline 12 & $\begin{array}{l}\text { I felt comfortable asking questions and contributing in- } \\
\text { class }\end{array}$ & 1 & 2 & 3 & 4 & 5 & 6 & 7 \\
\hline 13 & The group assignment helped me to master the material & 1 & 2 & 3 & 4 & 5 & 6 & 7 \\
\hline 14 & The profe & 1 & 2 & 3 & 4 & 5 & 6 & 7 \\
\hline 15 & Grading of assignments and exams was fair and clear & 1 & 2 & 3 & 4 & 5 & 6 & 7 \\
\hline 16 & $\begin{array}{l}\text { I felt in control of the material and my success in this } \\
\text { class }\end{array}$ & 1 & 2 & 3 & 4 & 5 & 6 & 7 \\
\hline 17 & I found the guest speakers to be valuable and interesting & 1 & 2 & 3 & 4 & 5 & 6 & 7 \\
\hline 18 & I am & 1 & 2 & 3 & 4 & 5 & 6 & 7 \\
\hline 19 & pectations & 1 & 2 & 3 & 4 & 5 & 6 & 7 \\
\hline 20 & I learned new forensic skills in this class & 1 & 2 & 3 & 4 & 5 & 6 & 7 \\
\hline 21 & $\begin{array}{l}\text { I believe IT knowledge and skills are important to my } \\
\text { career }\end{array}$ & 1 & 2 & 3 & 4 & 5 & 6 & 7 \\
\hline 22 & $\begin{array}{l}\text { I learned relevant forensic accounting knowledge in this } \\
\text { class }\end{array}$ & 1 & 2 & 3 & 4 & 5 & 6 & 7 \\
\hline 23 & $\begin{array}{l}\text { The web-based forensic tools were important learning } \\
\text { aids }\end{array}$ & 1 & 2 & 3 & 4 & 5 & 6 & 7 \\
\hline 24 & $\begin{array}{l}\text { Applying the forensic tools to audit problems increased } \\
\text { my understanding of the forensic techniques }\end{array}$ & 1 & 2 & 3 & 4 & 5 & 6 & 7 \\
\hline 25 & I would recommend this class to a friend & 1 & 2 & 3 & 4 & 5 & 6 & 7 \\
\hline
\end{tabular}


Journal of Digital Forensics, Security and Law, Vol. 5(2) 